\title{
Retirement decision-making influenced by family and work relationships
}

Desirée Ariane Modos Figueiral

Maria do Carmo Lourenço Haddad²

Raquel Grozd ${ }^{2}$

Paloma de Souza Cavalcante Pissinati ${ }^{3}$

\section{Abstract}

Objective: To identify the influence of family and work relationships on decision-making about retiring. Methods: A qualitative descriptive study was carried out with 16 pre-retirees from a public university institution located in the north of Paraná, Brazil. Data were collected between July and November 2012 from three reflection groups that discussed aspects related to retirement. The Content Analysis technique was chosen for data analysis. For the theoretical basis of the results, the Theory of Social Representations was used. Results: Two categories emerged from discourse analysis: The influence of family relationships on decision-making about retiring and the influence of work relationships on decision-making about

Keywords: Retirement. Family Relations. Work. retiring. Conclusion: Family and work experiences influence decision-making about retiring, and become more important when the pre-retiree does not have post-career life projects, demonstrating the importance of the participation of workers in strategies to prepare for retirement during working life.

\footnotetext{
Universidade Estadual de Londrina, Programa de Residência em Gerência dos Serviços de Enfermagem. Londrina, Paraná, Brasil.

2 Universidade Estadual de Londrina, Departamento de enfermagem. Londrina, Paraná, Brasil.

3 Universidade Estadual de Maringá, Programa de Doutorado em enfermagem. Maringá, Paraná, Brasil.
} 


\section{INTRODUCTION}

Retirement is a period of transition and changes that is strongly associated with job loss. It can represent recognition for the years dedicated to work and a period of freedom to carry out activities that work had made impossible. On the other hand, it can mean the need to confront aging and potential diseases $^{1}$, as well as feelings of worthlessness and unproductiveness in a societal context. All these interpretations bring the possibility of a new life, with new projects and possibilities ${ }^{2,3}$.

Considering the meanings and centrality that work occupies in human life, the difficulties in dealing with the consequent ruptures that retirement brings are understandable. Several activities of interest to individuals are encompassed in work, based in the environment where much of human sharing takes place, represented by important sources for the exchange of experiences, relationships and life events that carry psychosocial meanings. This reflects on how workers perceive their work, their involvement and satisfaction with it, as well as the marks left by the profession ${ }^{2,4,5}$.

When an individual is faced with the need to make decisions regarding retirement, questions arise regarding the human feelings and values that can affect this process ${ }^{2}$. It is important to emphasize that human beings are affected by influences from the environment in which they live, and, when faced with indecision over the issue of retirement, can begin to consider the external opinions of family, friends and co-workers, which often affect the complex decision that this moment of life demands ${ }^{6}$.

Studies have therefore observed the importance of family and friends, whether from the work environment or other contexts, in the decision making process regarding retirement and the possible changes caused in relationships of family and/or friendship, as the individual is divided between the worlds of family and work ${ }^{2,7}$. It is believed that pre-retirees whose families and friends positively influence the retirement decision will have more optimistic attitudes toward the overall benefits, time for relationships and a new beginning that retirement offers ${ }^{8}$.
The present study is of great importance due to its investigation of the social influences that permeate decision making regarding retirement, as it can serve as a support for the understanding of this moment that pre-retirees face and the identification of the influences, whether positive or negative, that affect this process. The study may also assist managers in the implementation of retirement preparation strategies that address the aspects that permeate the decision making related to this phase of life.

In view of such considerations, the objective of the present study was to reveal the influence of family and work relations on the decision-making process related to retirement.

\section{METHOD}

A qualitative and descriptive study was carried out at a public university institution located in Londrina, Paraná, Brazil, with approximately 5,266 employees. The survey included pre-retirees who, after participating in a cycle of instructional lectures in the Retirement Preparation Program in 2011, agreed to participate voluntarily in retirement thinktanks that took place in 2012. The aim of these groups was to promote discussions and reflections that could contribute to dealing with the feelings that emerge in the phase preceding retirement.

Of the 120 participants who attended the instructional lectures and were invited to participate in the reflection groups, 20 pre-retirees voluntarily enrolled for the latter stage, forming three groups. The first group contained eight pre-retirees, the second five, and the third seven. Participants were allocated in groups based on availability within their schedules. Four participants were excluded from the study because they attended only one meeting, giving a total population of 16 workers. It was decided to include only pre-retirees who participated in two or more meetings as it was considered that they had the minimum familiarity necessary with the subjects discussed in the discussions.

Five monthly meetings were held between July and November of 2012, with a duration of approximately two hours each. These were coordinated by a faculty 
member with professional experience in group dynamics and in research on the subject of retirement. One of the researchers of this study participated as an observer, recording the data and information from the discussions of each meeting in a field diary. Audio and video recording equipment were not used for data collection as the population was considered vulnerable in the context under discussion, and it was thought that these appliances could suppress the participation of pre-retirees in the discussions. It was chosen to record the data in field diaries.

The topics addressed at each meeting were not pre-established by the researchers. The discussions permeated the individually expressed desires that contributed to the collective construction of the representation of retirement for the group. At the beginning of each meeting, the coordinator returned to the previously discussed themes, in order to identify the reflections triggered in the previous meeting and which would be followed-up in later discussions.

The content analysis technique was used for data analysis, and contained the following steps: preanalysis, exploration of material, treatment of results and interpretations. When describing the discourses, the letter P (Participant) was assigned followed by a number corresponding to the pre-retiree in question, to preserve their identity.

The Theory of Social Representations (TRS) ${ }^{10}$ was used as a theoretical reference, as pre-retirement presents itself as a moment of choice and decisionmaking, in which the individuals seek to explore more deeply meanings and similarities together with their peers. In this way, the theory of social representations suggests that representations are present in all human interactions, influencing the behavior of the individual participant in a collective.

In this context, social representations aim to make communication within a group relatively unproblematic and reduce "vagueness" through a certain degree of consensus among its members, making it favorable for people and groups to transform ideas and images into a concrete reality ${ }^{10}$.

The study was approved by the Ethics Research Committee of the institution, under approval number
171/2010. All the participants signed a Free and Informed Consent Form.

\section{RESULTS AND DISCUSSION}

Sixteen pre-retirees participated in this study, of which 13 were female and three were male; the age range ranged from 48 to 68 years. Thirteen participants worked in administrative positions and three were faculty members.

The analysis of the discourses from the reflection groups led to the construction of two categories, based on the family and work influences that affect the retirement decision making process, identified in the discourse of participants and described below: the influence of family relationships on decision making about retirement and the influence of work relationships on decision making about retirement.

The influence of family relationships

on decision making about retirement

Pre-retirees are influenced by the family in making retirement decisions, with family relationships being a symbol of resilience for the challenges to be overcome ${ }^{8}$.

In terms of conjugal relationships, spouses have an important role in this stage of life, and the more satisfactory the conjugal relationship and the sense of companionship, the greater the propensity to retire. The following accounts demonstrate this explanation:

\footnotetext{
"My husband is my companion, not a hindrance to my retirement" (P1).

"I decided to retire because my husband retired as well" (P7).

“[...] my husband thinks I should stop" (P8).
}

The discourses described lead to the reflection that retirement can provide more time for coexistence and proximity between couples, which benefits the search for the pleasures of common life and satisfaction in the conjugal and family relationship. The proximity 
of the spouses at this stage may be related to the fact that their children have permanently left home, making it a space of free interaction between the couple. This allows for pleasurable moments by sharing domestic activities and leisure together ${ }^{8,11}$.

It should be emphasized that the affective bonds between husband and wife should be narrowed and strengthened during this period, especially in the face of a life plan that includes a meeting of interests, companionship in leisure activities and partnership in investments for the future ${ }^{5}$.

Similarly, as a harmonious marriage relationship may influence the desire to retire to be closer to one's partner, some participants reported that retirement could be a difficult time with their spouses, leading to the postponement of retirement. The following examples illustrate the above:

\footnotetext{
"My husband complains all the time when I come home. I tell him he's not the same person I married 28 years ago. I tell him that as soon as I put my foot in the door he starts complaining. It doesn't make me want to go home" (P2).

"My wife is very angry, and that's why I don't want to retire. If I'm in the house for one minute she complains" (P3).
}

The dialogues of $\mathrm{P} 2$ and $\mathrm{P} 3$ reveal that family dynamics influence the life of the retiree, as when these relationships are not harmonious and the retiree has no occupation outside the family, the increased time spent in the home can generate problems in the conjugal relationship and relations with other family members. This situation is exacerbated by the onset of old age, characterized by the feeling of career finitude, loss of vitality, fragility of health, illness, dependence and social rejection. The combination of these and other factors further disturbs relationships and weakens the health of the individuals ${ }^{11,12}$.

Another difficulty reported in the marital relationship refers to the dependence one spouse has on the other, which may frustrate the expectation of freedom associated with retirement:

"I don't like this dependence, I'd like him (my husband) to give me a bit more space" (P8).
Giving up work can generate a feeling of liberation and of an opportunity to accomplish what was left behind, a moment of rest, a lack of commitment, and to take part in activities that the work routine did not allow ${ }^{4,5}$. It is also considered that the decision to retire consists of a determining moment in the life of the individual, as it is a rupture with something concrete, namely work, which is replaced with a new life situation, resulting in a search for explanation of something that is uncertain and disturbing ${ }^{10}$. In this sense, the fact that the preretiree feels such dependence on the part of their spouse generates a feeling of a loss of the privacy and individuality necessary to reflect on the phase being experienced, given that the decision is often made in favor of the other.

The discourses also showed that the views of children can interfere with the decision to retire, as many encourage their parents to stop working and enjoy this new stage of life. On the other hand, there are children whose influence favors continuing at work, as they believe in the vitality of their parents and the benefits provided by work, or even to avoid the suffering caused by the feeling of "empty nest".

"I feel pressurized to stop working by my family $[\ldots] "$ (P1).

"My children don't want me to stop, they think I'm very young [...]” (P8).

"I still suffer from empty nest syndrome, I'm scared this will surface again when I stop working” (P1).

The Theory of Social Representations explains such ambivalent influences from children, and emphasizes that understanding external stimuli and explaining what they are and what they mean is the first step in any situational or social relationship analysis, and a means of predicting the evolution of interactions between people. In this way, the situation determines both the questions to be formulated and the answers to be provided, being the mediating representations between the stimulus and the respons $\mathrm{e}^{10}$. The influence of their children generates a reaction to the stimulus that occurs among the pre-retirees when making decisions about retirement, when the current condition of life is rethought and the future concretized, whether by retiring, or remaining in the labor market. 
Another aspect related to the relationship between parents and children refers to the relevance that the parents of the pre-retirees have in postcareer decision making, as many opt for retirement to dedicate more time and attention to such relatives. Comments that exemplify this include:
The discourses show that pre-retirees, in an uncomfortable situation, seek their own understanding of their reality and desires, in order to concretize ideas and feelings. They postpone retirement when family and friends seek to plan their post-career path with chores and the imposition of relationships of dependency ${ }^{10}$.

The possibility of having their retirement tasks defined by family and friends in retirement may also be a consequence of the lack of well-defined post-career life plans. When the time comes for retirement, the individual perceives themselves to be faced with a reality for which they have not prepared, making themselves more vulnerable to the imposition of certain conditions ${ }^{12,13}$.

Uncertainty regarding the emotional support of the family during retirement also raises questions regarding this life decision:

"In what way are my family going to support me
in retirement?" (P2).

"When I get home I have an urge to run away, because my son is a very good boy, but he's very quiet [...] it really bothers me" (P4).

The concerns described lead to the perception that the transition into retirement is experienced differently by people depending on their experience with work, development of skills, coping and resilience abilities, living conditions and other aspects. Therefore, the possibilities for healthy adaptation and the reduction of stress are related to autonomy and independence, affective support and social integration with family, spouse and friends, in order to maintain health and provide motivation for and interest in continuity projects ${ }^{14}$. Investigations that examine family relationships when faced with retirement are important, as a review study verified that research in Brazil addresses the relationship between retirement and the family context only superficially, with the focus of research also exploring other themes. International databases, meanwhile, reveal six publications on this theme in eleven years of research ${ }^{15}$.

A reflection on retirement and its impact on personal and professional life, especially in the family 
context ${ }^{15}$, is therefore important, and may allow this period of life to be satisfactory and based on the support and restructuring of family life.

\section{The influence of work relationships on decision-making about retiring}

In addition to family influences, pre-retirees are influenced by co-workers when making decisions about retirement. Many encourage the worker to choose retirement either because of a desire to take their place, or by believing in the need to renew the workforce. The following discourses exemplify the above:

"My younger colleagues see me as a competitor, they ask me when I'm going to stop working, they want my job [...] They want my place, they even know the day I can retire" (P5).

“The younger ones say to me: 'Aren't you going to retire?' I don't feel bad, I say that if I want to leave, I'll leave, and if I want to stay, I'll stay. [...] We have the knowledge and the wisdom, but we haven't mastered computers" (P4).

Such explanations lead to an understanding of the social representations that constantly arise in human relations, when one individual confronts the other with intentions and purposes and which occur for practical reasons. Everything that people do or say can have a hidden meaning, intention or purpose, which others try to understand ${ }^{16}$. In expressing inquiries regarding the departure or permanence of the pre-retiree at work, co-workers lead such individuals to a reflection regarding their role in the institution and their future prospects, which can lead to retirement.

Workers can remain at the same company for many years, especially in public institutions, and postpone their retirement due to their financial stability. As a result, the number of aging employees at the institution increases and, as their capacity for work diminishes, stigmas and prejudices related to productivity arise in this environment. In addition, the chronological factor exerts an influence in the evaluation of the activity or inactivity of human beings and imposes the idea of unproductiveness and dependency on the elderly, resulting in discrimination against them ${ }^{3,6,17}$.

Studies have shown the embrittlement of the health of workers with advancing age, characterized by cognitive and psychomotor decline, loss of functional capacity and autonomy, as well as the appearance of chronic diseases and the use of more medications than younger workers. Therefore, the pre-retirement period associated with aging can result in a decrease in work performance and lead to non-adherence to the digital world and technological advances, which intensifies the rejection of the same by colleagues ${ }^{3,17-19}$.

Other factors that exert a favorable influence on retirement refer to the fact that pre-retirees feel the absence of colleagues who have retired, and thus perceive themselves in an environment that is no longer familiar to them, or when resentment arises with those who remain working in the workplace, generating conflicts. On the other hand, some work influences lead the pre-retiree to the desire to postpone retirement. These are strongly associated with the relations of friendship established at work, and are related to trust and emotional support.

"I really like to work, but today I don't take as much pleasure as I used to in my area. My colleagues have already retired as well" (P8).

"I was sure that I wouldn't want to retire [...] I didn't have any problems with my colleagues, the long-standing ones, for over 35 years. [...] The competition at work has been difficult. [...] Events have made me rethink [...]" (P1).

"My biggest concern about retirement is not having my work colleagues around to let off steam [...]. My family is great, but I can't talk to them about things I can only talk about to my co-workers, not even my sister. [...]I come here and get my worries off my chest, but what about when I don't have this anymore?” (P7).

It is accepted that work represents the best way to serve and be served, and is an experience with pleasant surprises, strong emotions, frustrations, uncontained joy, and also sorrow ${ }^{5}$. 
Many experiences, stories, struggles and achievements are shared in the work environment, and in some cases friendships are restricted to such places. These relationships help the worker develop resilience and produce strategies to deal with disturbing events. In this sense, retirement can mean the end of this bond ${ }^{7,20}$.

Social integration at work provides a better quality of life and work, generates pleasure, reliability, and helps in the process of dealing with adversities, making the environment more pleasant. On a daily basis, the worker is exposed to routine circumstances related to the overload of activities, stress, the privileges of some colleagues, conflicting situations, all of which involve different personalities and possible betrayals, which can lead to the breaking of relationships of friendship within the institution ${ }^{20}$.

Another factor that weighs against retirement and was highlighted by the participants relates to the statements of colleagues and friends regarding the positive mood of the pre-retiree, assuring them that they have much contribute to the institution and that work does them good, as expressed below:

"The external influences of my workmates make things difficult, they say I still have a lot to contribute" (P14).

"My friends say that I always look nice, I make myself look smart for work like it's a party, because I feel happy when I go to work" (P1).

"I get a lot of affection from my students, they ask me not to retire" (P3).

The above statements relate to the understanding that people tend to consider and analyze the world in a similar way, especially when the world in which they live is entirely social ${ }^{10}$. This means that the opinions expressed by co-workers interfere in decision making in this phase of life, when the pre-retiree unconsciously shares the opinions of their peers.

Such influences lead the pre-retirees to reflect on the pleasure generated by the relationships that motivate their decision to continue working, bringing dignity and personal satisfaction. These come from the valorization and recognition obtained through actions carried out within the community, with the creation of bonds of trust and friendship. This context is important even for the mental health and selfesteem of individuals, as it contrasts with the stigma of an old, excluded, incapacitated and unproductive person that is often attributed to retirees ${ }^{17,21}$.

Because the strategies established to guide the groups did not define the discussion topics for each meeting, the reflections of the participants were restricted to the family and work influences on decision making regarding retirement. This was a limitation of this study as it did not cover all the aspects that influence this process. These results may differ among other populations, as the individual characteristics of these groups contributed to their reflections on retirement.

\section{CONCLUSIONS}

The proximity of retirement leads employees to reflect on their work and their personal and family life, thereby raising the possibility of listening to opinions of family and friends and observing family and work factors that can aid in the difficult process of making decisions about retiring.

The results showed that some family and work experiences significantly influence why pre-retirees choose retirement or decide to continue working.

The benefits of retirement were described by those with good family relationships, especially with their spouses, and who wish to have time to perform other activities without the commitment of work. Another factor observed was related to the increased demands of caring for parents who are ill. There were also cases in which workers described feeling unfit for the work environment, whether due to difficulties related to aging, problems with relationships, and even unhappiness.

Pre-retirees who were unfavorable to the idea of retirement were those with disharmonious family relationships, those who fear the dependence of having to look after their grandchildren, and those who do not receive emotional support from home. In relation to the working environment, workers who maintain a strong bond of friendship with coworkers and those who are satisfied with their duties and are valued are unfavorable to retirement. 
Emphasis should be placed on the important role that employers should play in this context through the preparation of strategies to prepare workers for retirement, in order to encourage them to reflect

\section{REFERENCES}

1. Canizares JCL, Jacob Filho W. Fatores de risco à senilidade na transição à aposentadoria. Rev Bras Geriatr Gerontol [Internet]. 2011 [acesso em 08 abr. 2016];14(3):425-32. Disponível em: http://www.scielo. br/pdf/rbgg/v14n3/v14n3a03.pdf

2. Panozzo EAL, Monteiro JKM. Aposentadoria e saúde mental: uma revisão de literatura. Cad Psicol Soc Trab. 2013;16(2):199-209.

3. Rebouças M, Matos MR, Ramos RR, Cecílio LO. O que há de novo em ser velho. Saúde Soc. 2013;22(4):1226-35.

4. Selig GA, Valore LA. Imagens da aposentadoria no discurso de pré-aposentados: subsídios para a orientação profissional. Cad Psicol Soc Trab. 2010;13(1):73-87.

5. Cuello MA, Concha LS. Preparación para la jubilacion em losservicios públicos de Chile. Rev Chil Ter Ocup [Internet]. 2011 [acesso em 05 abr. 2016];11(11):53-64. Disponível em: http://www.revistaterapiaocupacional. uchile.cl/index.php/RTO/article/viewFile/17082/17819

6. Araújo LP. Aposentadoria como proposta de qualificação para uma vida saudável. Rev Incelências. 2011;2(2):63-77.

7. Soares DHP, Luna IN, Lima MBF. A arte de aposentar-se: programa de preparação para a aposentadoria com policiais federais. Estud Interdiscip Envelhec. 2010;15(2):293-313.

8. Franca LHFP, Menezes GS, Siqueira AR. Planejamento para aposentadoria: a visão dos garis. Rev Bras Geriatr Gerontol [Internet]. 2012 [acesso em 12 abr. 2016];15(4):733-45. Disponível em: http://www.scielo.br/pdf/rbgg/v15n4/12.pdf

9. Bardin L. Análise de conteúdo. Lisboa: Edições 70; 2010.

10. Moscovici S. Representações sociais: investigações em psicologia social. G $^{a}$ ed. Petrópolis: Vozes; 2009.

11. Zanelli JC. Processos psicossociais, bem-estar e estresse na aposentadoria. Rev Psicol Trab. 2012;12(3):329-40.

12. Santos VB, Tura LFR, Arruda AMS. As representações sociais de "pessoa velha" construída por idosos. Saúde Soc. 2013;22(1):138-47. on their personal and professional life to ensure a satisfactory decision-making process and, finally, support them by planning life projects that provide a structured post-career life.
13. Chrisostomo ACR, Macedo R. O trabalho segundo a visão de um grupo de aposentados. Rev Kairós. 2011;14(1):149-61.

14. Fernandes GMF, Garcia GG. O sentido da velhice para homens e mulheres Idosos. Saúde Soc. 2010;19(4):771-83.

15. Cruz MAG. Adiando a aposentadoria: um estudo sobre os fatores que levam servidores federais a adiar a aposentadoria em uma instituição de pesquisa [dissertação]. Taubaté: Universidade de Taubaté; 2011.

16. Zanelli JC, Silva N, Soares DH. Orientação para aposentadoria nas organizações de trabalho: construção de projetos para o pós-carreira. Rev Psicol Organ Trab [Internet]. 2010 [acesso em 10 abr. 2016];10(2):177-81. Disponível em: http://pepsic. bvsalud.org/pdf/rpot/v10n2/v10n2a13.pdf

17. Antunes MH, Soares DHP, Silva N. Aposentadoria e contexto familiar: um estudo sobre as orientações teóricas da produção científica. Perspect Gest Conhec. 2013;3(Esp):45-56.

18. Padula RS, Comper MLC, Moraes AS, Sabbagh C, Pagliato Junior W, Perracini MR. The work ability index and functional capacity among older workers. Braz J Phys Ther [Internet]. 2013 [acesso em 10 abr. 2016];17(4):382-91. Disponível em: http://www.scielo.br/ pdf/rbfis/v17n4/pt_1413-3555-rbfis-nahead2332012.pdf

19. Mancini RB, Matsudo SM, Matsudo V. Função cognitiva e capacidade funcional em mulheres acima de 50 anos de idade. J Aging Innov. 2014;3(1):15-25.

20. Schujmann A. A influência da promoção nas relações de amizade no ambiente de trabalho [dissertação]. Porto Alegre: Universidade Federal do Rio Grande do Sul; 2010.

21. Brito J, Bercot R, Hourellou-Lafarge CH, Neves MY, Oliveira S, Rotemberg L. Saúde, gênero e reconhecimento no trabalho das professoras: convergências e diferenças no Brasil e na França. Physis [Internet]. 2014 [acesso em 12 abr. 2016];24(2):589605. Disponível em: http://www.scielo.br/pdf/physis/ v24n2/0103-7331-physis-24-02-00589.pdf 